\title{
HAK ASASI MANUSIA BAGI PENYANDANG DISABILITAS DALAM MENDAPAT PEKERJAAN YANG LAYAK TANPA ADANYA DISKRIMINASI
}

\author{
Pramadita Hasbullah", Rahayu*
}

\begin{abstract}
People with disabilities are a minority community in the world. Communities who consider that persons with disabilities have limitations that interfere with their activities, especially in working to make discrimination of the rights of people with disabilities. Governments in various countries of the world have issued various regulations that support the realization of the rights of people with disabilities, especially in getting a job. The purpose of writing this article is to find out how legal protection for people with disabilities who experience discrimination in the world of work. Type of writing using normative legal writing that produces descriptive data analysis. Government laws and regulations have been established to prohibit discrimination on the basis of disability of all forms of employment, but the unavailability of information services and lack of care for disability workers is still a hindrance.
\end{abstract}

Keywords : Human Rights, Disability, Discrimination, Workers with disabilities.

\section{PENDAHULUAN}

Menurut penelitian Santuzzi dan Waltz (2016 hlm.1) dalam literatur manajemen dan sains sosial mengenai kecacatan di tempat kerja, menunjukkan kurangnya penghargaan terhadap pekerja yang memili kecacatan. Di dunia telah banyak dukungan dan aspirasi mengenai pendekatan baru untuk kebutuhan dan disabilitas pendidikan khusus, mem prioritaskan fokus umum pada perlakuan khusus. ${ }^{1}$ Semua penyandang cacat men dapatkan pengakuan yang memadai dan

* Pramadita Hasbullah, Mahasiswa Program Studi Magister Ilmu Hukum UNDIP dapat dihubungi melalui email : hasbullah94@outlook.com

Rahayu, Dosen Program Studi Magister Ilmu Hukum UNDIP

1 Santuzzi, A. M., P. R. Waltz. 2016. Disability in the Workplace: A Unique and Variable Identity. Journal of Management, 20 (10) hlm. 1

2 Lockwood, G., Claire, H., G. Thornicroft. 2014. Mental health disability discrimination: Law, policy and practice. International Journal of Discrimination and the Law, 14(3) hlm.153 konsisten. (Hardy and Woodcock, 2015 hlm. 153)

Undang-Undang Nomor 8 Tahun 2016 Pasal 1 ayat (1) tentang Penyandang Disabilitas mengatur bahwa yang dimaksud dengan; "Penyandang Disabilitas adalah setiap orang yang mengalami keterbatasan fisik, intelektual, mental, dan/atau sensorik dalam jangka waktu lama yang dalam berinterkasi dengan lingkungan dapat mengalami hambatan dan kesulitan untuk berpartisipasi secara penuh dan efektif dengan warga negara lainnya berdasarkan kesamaan hak."

Penyandang Disabilitas merupakan masyarakat minoritas di dunia. Masyarakat yang menganggap bahwa penyandang disabilitas mempunyai keterbatasan yang mengganggu aktivitasnya terutama dalam bekerja membuat hak penyandang disabilitas terabaikan bahkan tidak ada rasa peduli terhadap hak yang dimiliki

3 Undang-Undang Nomor 8 Tahun 2016 tentang Penyandang Disabilitas 
oleh penyandang disabilitas, padahal didalam Undang-Undang Dasar 1945 Pasal 27 ayat (2) mengatur bahwa; "Tiap-tiap warga negara berhak atas pekerjaan dan penghidupan yang layak bagi kemanusia an", kemudian diperjelas di dalam Pasal 28 D yang mengatur bahwa; "Setiap orang berhak untuk bekerja serta mendapatkan imbalan dan perlakuan yang adil dan layak dalam hubungan kerja." Hak bekerja bagi setiap warga negara sudah diatur di dalam Peraturan Perundang Undangan terutama dalam Undang-Undang Dasar $1945 .^{4}$

Dimana dalam Undang-Undang tersebut tidak membatasi seseorang yang mempunyai keterbatasan fisik dan / atau intelektual untuk mendapatkan hak bekerja nya, sehingga setiap orang tanpa terkecuali dapat menikmati haknya sesuai dengan Peraturan Perundang-Undangan. Konvensi Hak-Hak Penyandang Disabilitas me maparkan secara jelas mengenai hak-hak penyandang disabilitas, diantaranya adalah:

1. Hak untuk mendapat persamaan dan non-diskriminasi

2. Hak untuk mendapat pelayanan atau aksesibilitas

3. Hak atas kebebasan dan keamanan

4. Hak untuk mendapatkan pengakuan atas persamaan di muka hukum

5. Hak untuk mendapat keadilan

6. Hak bebas dari penyiksaan atau penghukuman yang kejam

7. Hak bebas dari eksploitasi dan kekerasan

8. Hak atas pendidikan dan kesehatan

9. Hak atas pekerjaan dan lapangan kerja

10. Hak kebebasan bergerak dan berkewarganegaraan

Hak-hak yang terdapat dalam Konvensi Hak-Hak Penyandang Disabilitas tersebut menjadi dasar bagi kaum penyandang disabilitas untuk mempertahan kan hidupnya serta memperjuangkan hak

4 Undang-Undang Dasar Republik Indonesia 1945 yang ada pada dirinya, namun dalam kenyataannya masih terdapat hak penyandang disabilitas yang diabaikan oleh Pemerintah, salah satunya adalah hak untuk bekerja dan memperoleh pekerjaan. (Kusumastuti, 2016 hlm. 2) $^{5}$

Hak atas pekerjaan dan lapangan keja yang dimaksud dalam Konvensi HakHak Penyandang Disabilitas adalah sebuah hak asasi manusia yang tidak bisa dipisah kan karena setiap manusia dan semua orang berhak untuk berpartisipasi, berkontribusi dan menikmati pembangunan ekonomi, sosial, budaya dan politik, dimana semua hak asasi manusia dan kebebasan yang mendasar bisa sepenuhnya diwujudkan.

Sebagai pelaksana Undang-Undang Penyandang Disabilitas telah dikeluarkan Surat Edaran Menteri Tenaga Kerja danTransmigrasi Nomor 01.KP.01.15.2002 tentang Penempatan Tenaga Kerja Penyandang Cacat di perusahaan yang mengamanatkan kepada setiap kepala Dinas Tenaga Kerja dan Transmigrasi untuk mensosialisasikan Undang-Undang Penyandang Disabilitas dan Peraturan (Hardjanti, 2016 hlm.7).

Perundang-Undangan lain terkait hak penyandang disabilitas dalam bekerja sebagai upaya penempatan tenaga kerja penyandang disabilitas di perusahaan karena di dalam Undang-Undang Nomor 43 Tahun 1998 tentang Upaya Peningkatan Kesejahteraan Sosial Penyandang Cacat khususnya Pasal 28 mengatur bahwa; "Pengusaha harus mempekerjakan sekurang - kurangnya 1 (satu) orang penyandang cacat yang memenuhi persyaratan jabatan dan kualifikasi pekerjaan pada perusahaannya untuk setiap 100 (seratus) orang pekerja pada perusahaannya", dan mengamanatkan untuk melakukan pendataan terhadap perusahaan yang memperkerjakan

5 Kusumastuti, M. N. S. A. (2016). Perlindungan Hukum Dari Diskriminasi Bagi Penyandang Disabilitas Dalam Dunia Kerja. Jurnal Universitas Atma Jaya Yogyakarta. Hlm. 2 
penyandang disabilitas setiap 3 (tiga) bulan sekali dan melaporakan hasil pendataan tersebut kepada Menteri Tenaga Kerja danTransmigrasi Direktorat Jenderal Binalatpedagri. (Kusumastuti, 2016 hlm.2). ${ }^{6}$

Penyandang Cacat khususnya Pasal 28 belum terlaksana dengan baik, dimana dalam Undang-Undang tersebut mengatur bahwa; "Pengusaha harus mempekerjakan sekurang-kurangnya 1 (satu) orang penyandang cacat yang memenuhi persyaratan jabatan dan kualifikasi pekerja an pada perusahaannya untuk setiap 100 (seratus) orang pekerja pada perusahaan nya."

Semakin banyak diskriminasi yang terjadi terhadap penyandang disabilitas, Pemerintah seharusnya secara tegas memberikan perlindungan hukum terhadap kaum penyandang disabilitas dan memberi kan kesempatan kepada kaum penyandang disabilitas untuk dapat bekerja seperti orang normal pada umumnya dan tidak memandang bahwa dengan keterbatasan yang penyandang disabilitas miliki dapat menghambat mereka dalam bekerja. Perlindungan hukum terhadap pekerja merupakan pemenuhan hak dasar yang melekat dan dilindungi oleh konstitusi sehingga pelanggaran terhadap hak dasar tersebut merupakan pelangggaran hak asasi manusia.

Perlindungan terhadap pekerja bertujuan untuk menjamin hak-hak dasar pekerja dan menjamin kesamaan serta perlakuan tanpa diskriminasi atas dasar apapun untuk mewujudkan kesejahteraan pekerja dengan tetap memperhatikan perkembangan kemajuan dunia usaha dan kepentingan pengusaha.

Pengusaha yang mempekerjakan tenaga kerja penyandang cacat wajib memberikan perlindungan sesuai dengan jenis dan derajat kecacatannya yang sesuai dengan Pasal 67 ayat (1) Undang-Undang Nomor 13 Tahun 2003 tentang Ketenaga kerjaan.

Bentuk perlindungan tersebut seperti penyediaan aksesibilitas, pemberi an alat kerja dan alat pelindung diri. Dalam upaya melindungi, menghormati, memajukan, dan memenuhi hak-hak penyandang disabilitas, Pemerintah Republik Indonesia telah membentuk berbagai peraturan perundang-undangan yang mengatur mengenai perlindungan terhadap penyandang disabilitas.

\section{METODE PENELITIAN}

Jenis penulisan yang digunakan adalah penulisan hukum normatif. Penulisan hukum dikonsepkan sebagai apa yang tertulis dalam peraturan perundang undangan (law in books) atau hukum yang dikonsepkan sebagai kaidah atau norma yang merupakan patokan perilaku manusia yang dianggap pantas. Penelitian hukum normatif menggunakan pendekatan normatif yuridis, artinya penelitian hukum ini berfokus pada norma hukum positif. Cara pengumpulan data yang dilakukan adalah dengan studi Kepustakaan. Studi kepustakaan dilakukan untuk mempelajari bahan hukum primer yang berupa peraturan perundang undangan, bahan hukum sekunder yang berupa pendapat hukum dan pendapat bukan hukum dari buku, hasil penelitian, jurnal hukum, majalah, surat kabar, internet, serta makalah tentang perlindungan hukum bagi penyandang disabilitas dalam dunia kerja.

Analisis Data yang digunakan untuk penelitian hukum ini diperoleh dari kepustakaan, kemudian diarahkan, dibahas dan diberi penjelasan dengan menggunakan metode analisa kualitatif, yaitu suatu cara penelitian yang menghasilkan data deskriptif analisis.

6 Hardjanti, D. K. (2016). Kajian Yuridis tentang Penyandang Disabilitas.Perspektif Hukum, 16 (1) hlm. 7 


\section{HASIL DAN PEMBAHASAN}

Komponen fungsi dan kecacatan muncul dalam fungsi Tubuh dan komponen struktur tubuh dan komponen Kegiatan dan Partisipasi. Fungsi tubuh didefinisikan sebagai fungsi fisiologis sistem tubuh. Struktur tubuh didefinisikan sebagai bagian anatomis tubuh seperti organ, tungkai, dan komponennya. Kegiatan didefinisikan sebagai pelaksanaan tugas atau tindakan oleh individu. Kegiatan bekerja dikaitkan dengan partispasi kerja. Partisipasi didefinisikan oleh keterlibatan dalam situasi kegiatan. Aktivitas dan Partisipasi dikelompokkan dalam satu daftar tetapi dikodekan dengan dua kualifikasi: kualifikasi kapasitas dan kualifikasi kinerja. Kualifikasi kapasitas menggambar kan kemampuan seseorang untuk menjalan kan atask atau tindakan di lingkunganyang seragam atau standar. Kualifikasi kinerja menggambarkan apa yang dilakukan seseorang dalam lingkungannya saat ini. kinerja dapat dipahami sebagai "keterlibatan dalam situasi kehidupan" atau "pengalaman hidup" orang-orang dalam konteks aktual di mana mereka tinggal (yaitu partisipasi), karena lingkungan saat ini membawa konteks asosial (WHO, 2001 Hal 229).

Adapun faktor yang mempengaruhi kondisi dunia kerja bagi para penyangdang disabilitas. Salah satu faktor tersebut yaitu faktor lingkungan. Faktor lingkungan didefinisikan sebagai faktor-faktor yang membentuk lingkungan fisik, sosial, dan sikap di mana orang tinggal dan melakukan kehidupan mereka. Ini mencakup faktorfaktor yang terkait baik langsung (misalnya, produk dan teknologi untuk mobilitas) dan lingkungan yang jauh lebih jauh (misalnya, sikap sosial, sistem, dan kebijakan) yang mungkin berdampak pada fungsi seseorang. Faktor lingkungan dikatakan memiliki dampak (yaitu, memfasilitasi atau menghambat) pada semua komponen fungsi dan kecacatan.
(Hemmingsson and Jonsson, 2005, hlm. 571). ${ }^{7}$

Beberapa dampak yang terjadi pada pekerja penyandang disabilitas menurut Krieger (2014 hlm. 674-677) ${ }^{8}$ yaitu :

1. Dampak langsung dari diskriminasi terhadap kesehatan dihasilkan dari adanya diskriminasi sistemik - dalam menjalankan sistem perawatan kesehatan, konsekuensi langsungnya adalah untuk menghalangi akses orang cacat terhadap perawatan kesehatan dan sosial yang sesuai.

2. Dampak tidak langsung dari diskriminasi terhadap kesehatan timbul melalui dua jalur yang saling terkait.

a). Pertama, sistem dan praktik diskriminatif berkontribusi pada pengucilan sosial penyandang cacat. Akibatnya, orang cacat lebih mungkin dibandingkan rekan mereka untuk terkena kondisi kehidupan (kemiskin an, pengangguran, kemalangan sosial, kontrol rendah, status rendah, perumahan yang buruk) yang terkait dengan kesehatan yang buruk.

b) Kedua, pengalaman langsung dan tidak langsung tentang diskriminasi disablisme dan kecacatan mungkin diharapkan berdampak negatif pada kesehatan mental dan fisik seseorang. Meskipun tidak ada bukti langsung yang tersedia untuk mendukung anggapan ini, proses setara (pengalaman rasisme dan diskriminasi rasial) telah diidentifikasi sebagai pusat untuk memahami ketidak setaraan etnis dalam kesehatan.

Secara eksplisit Indonesia memiliki Undang-Undang Nomor 8 Tahun

7 Hemmingsson, H., \& Jonsson, H. (2005). The issue is-An occupational perspective on the concept of participation in the international classification of functioning, disability and health-Some critical remarks. American Journal of Occupational Therapy, 59. Hlm. 571

8 Krieger, N. 2014. Discrimination And Its Consequences For Health : Discrimination And Health Inequities. International Journal of Health Services, 44 (4) hlm. 674-677 
2016 tentang Penyandang Disabilitas yang disahkan pada tanggal 15 April 2016 dimana Undang-Undang ini memberikan landasan hukum secara tegas mengenai kedudukan dan hak penyandang disabilitas. Dalam konsideran Undang Undang Penyandang Disabilitas ditegaskan bahwa; "Negara Kesatuan Republik Indonesia menjamin keberlangsungan hidup setiap warga Negara, termasuk para penyandang disabilitas yang mempunyai kedudukan hukum dan memiliki hak asasi manusia yang sama sebagai warga negara Indonesia dan sebagai bagian yang tidak terpisahkan dari warga negara dan masyarakat Indonesia merupakan amanah dan karunia Tuhan Yang Maha Esa, untuk hidup maju dan berkembang secara adil dan ber martabat."

Selain hak-hak fundamental yang disebutkan dalam Undang-Undang Penyandang Disabilitas, hak penyandang disabilitas juga ditegaskan dalam Pasal 41 ayat (2) Undang-Undang Nomor 39 Tahun 1999 tentang Hak Asasi Manusia, yang menyebutkan bahwa; "Setiap penyandang cacat, orang yang berusia lanjut, wanita hamil dan anak-anak, berhak memperoleh kemudahan dan perlakuan khusus," dan pada Pasal 42 menyebutkan bahwa;"Setiap warga Negara yang berusia lanjut, cacat fisik dan/atau cacat mental berhak memperoleh perawatan, pendidikan, pelatihan, dan bantuan khusus atau biaya negara, untuk menjamin kebutuhan yang layat sesuai dengan martabat kemanusiaan nya, meningkatkan rasa percaya diri, dan kemampuam berpartisipasi dalam kehidup an bermasyarakat, berbangsa, dan bernegara. "Seperti yang telah diuraikan dalam Undang-Undang Penyandang Disabilitas dan Undang-Undang Hak Asasi Manusia, penyandang disabilitas mempunyai hak dan kewajiban yang sama seperti orang normal. (Hardjanti, $2016 \mathrm{hlm}$. 3). ${ }^{9}$ Penyandang cacat terdapat di semua bagian dunia dan semua tingkatan dalam setiap masyarakat. Jumlah penyandang cacat di dunia ini besar dan senantiasa bertambah. Baik penyebab maupun akibat kecacatan di dunia ini bervariasi. Variasi tersebut diakibatkan oleh perbedaan keadaan sosial ekonomi dan sarana serta prasarana yang dapat disediakan oleh Negara untuk kesejahteraan warganya. Kebijaksanaan dalam bidang kecacatan masa kini merupakan hasil perkembangan selama dua ratus tahun terakhir.

Dalam studi penelitian Kulkarni $(2016 \text { hlm 1) })^{10}$ menyatakan bahwa di India, pandangan bahwa pengembangan karir dapat dipengaruhi oleh organisasi, inisiatif pengusaha yang bertujuan mengembang kan karir karyawan penyandang cacat. Melalui 17 wawancara mendalam di negara-negara yang memiliki reputasi tinggi di India dengan personil sumber daya manusia di perusahaan yang dikenal karena kebijakan yang baik dalam mempekerjakan orang-orang penyandang cacat, para pengusaha telah membantu dan terus berusaha untuk membantu mereka yang memiliki kecacatan mencapai kesuksesan karir. Penelitian sebelumnya yang telah mencatat hambatan keberhasilan karir dan menguraikan bagaimana para pengusaha dan praktisi sumber daya manusia dapat membantu mengembangkan karir karyawan penyandang cacat. Praktik sumber daya manusia tertentu termasuk menggunakan bahasa atau terminologi yang tepat untuk merujuk pada orang-orang penyandang cacat, program sensitisasi yang ditujukan kepada anggota organisasi termasuk penyandang cacat, akomodasi untuk semua karyawan, audit akomodasi untuk memastikan aksesibilitas di tempat kerja, mempublikasikan kisah sukses para karyawan termasuk Mereka yang cacat dan

9 Hardjanti, D. K. (2016). Kajian Yuridis tentang Penyandang Disabilitas.Perspektif Hukum,16 (1) $\mathrm{hlm} .3$

10 Kulkarni, M. 2016. Organizational career development initiatives for employees with a disability. The International Journal of Human Resource Management. Hlm. 1 
berfokus pada program pengembangan kemampuan.

Perserikatan Bangsa-Bangsa menegaskan bahwa keprihatinan orangorang penyandang cacat mental tidak mendapat prioritas sama sekali daripada banyak pihak lain yang mendesak perhatian melalui forum internasional. Perserikatan Bangsa - Bangsa telah mengakui bahwa cara di mana pemerintah memberikan perawatan kesehatan mental menimbulkan masalah hak asasi manusia internasional. Negara harus memberikan panduan terperinci mengenai penerapan hak berbasis perjanjian kepada orang-orang dengan cacat mental. Masyarakat inter nasional harus memperluas agenda hak asasi manusia untuk menciptakan tuntutan yang kuat terhadap pekerja disabilitas. Orang-orang dengan disabilitas diberi perhatian pada Konvensi PBB tentang Hak Penyandang Cacat (UN Convention on the Rights of Persons with Disabilities). Perundang-undangan kesehatan mental konvensional, seperti Undang-Undang Kesehatan Mental (Mental Health Act) di Inggris dan Wales tampaknya melanggar, misalnya, Pasal 4 : "tidak ada diskriminasi dalam bentuk apapun atas dasar kecacatan", Pasal 12 : "orang-orang akan memenuhi persyaratan hukum pada Dasar kesetaraan dengan orang lain dalam semua aspek kehidupan" dan Pasal14 : "adanya kecacatan sama sekali tidak membenarkan perampasan kebebasan". (Szmukler, et al., $2014 \mathrm{hlm} 245)^{11}$

Salah satu yang merupakan perwujudan dari perhatian pemerintah yaitu adanya Konvensi Internasional Hakhak Penyandang Disabilitas terbentuk berdasarkan pada pertimbangan sebagai mana telah dinyatakan dalam prinsipprinsip Piagam PBB yang mengakui martabat dan harkat yang melekat dan hak-

11 Szmukler, G, Rowena, D., Felicity, C. 2014. Health Law And The UN Convention On The Rights Of Persons With Disabilities. International Journal of Law and Psychiatry 37. Hlm. 245 hak yang setara dan tidak dapat dicabut dari semua anggota umat manusia sebagai dasar dari kebebasan, keadilan dan perdamaian di dunia. Dalam konvensi ini, PBB menegaskan kembali tentang makna universalitas, sifat tidak terbagi-bagi, saling ketergantungan dan saling keterkai an antara semua hak asasi manusia dan kebebasan mendasar dan kebutuhan orangorang penyandang cacat untuk dijamin sepenuhnya atas hak asasi manusia dan kebebasan mendasar tersebut tanpa diskriminasi.

Undang-undang Nomor 19 Tahun 2011 tentang Konvensi Internasional Hakhak Penyandang Disabilitas atau The Convention on The Rights of Persons with Disabilities (CRPD) mengamanatkan bahwa kewajiban Negara Indonesia sebagai Negara yang menandatangani konvensi untuk melakukan penyesuaian peraturan perundang-undangan.

British Council of Disabled People telah mengadopsi definisi berikut: Cacat adalah kerugian atau pembatasan aktivitas yang disebabkan oleh masyarakat yang hanya sedikit atau tidak memperhitungkan orang-orang yang memiliki gangguan dan karenanya mengecualikannya dari aktivitas arus utama. Oleh karena itu, kecacatan, seperti rasisme atau seksisme, adalah diskriminasi dan penindasan sosial. Dibutuhkan etika perlakuan yang didasar kan pada bahwa setiap orang memiliki hak asasi manusia yang sama, juga mengakui persyaratan tambahan yang dimiliki beberapa orang untuk mengakses hak asasi tersebut. Konsep hukum tentang diskriminasi kecacatan diperkenalkan pada tahun 1995 ketika Disability Discrimination Act (Undang-Undang Diskriminasi Cacat) disahkan oleh Parlemen. Perundang-undangan tersebut kemudian diubah pada tahun 2001 dan 2005. Ketentuan saat ini tercantum dalam Equality Act (Undang-Undang Kesetaraan) Tahun 2010, yang mendefinisikan kelainan sebagai gangguan fisik atau mental yang 
memiliki dampak buruk substansial dan jangka panjang terhadap kemampuan untuk melakukan kegiatan sehari-hari. Undangundang tersebut melarang beberapa jenis diskriminasi, yaitu :

1. Diskriminasi langsung, di mana orang diperlakukan dengan kurang baik karena kecacatan mereka daripada orang-orang yang tidak memiliki kecacatan akan diperlakukan dalam situasi yang sama.

2. Diskriminasi tidak langsung, yang berarti bahwa seorang karyawan dapat memperdebatkan bahwa praktik, kriteria atau ketentuan merugikan orang-orang yang memiliki kecacatan yang sama seperti pemohon. Tidak perlu menunjukkan bahwa atasan mengetahui atau seharusnya mengetahui bahwa pemohon telah dinonaktifkan.

3. Diskriminasi kecacatan yang timbul dari kecacatan. Ini berarti seseorang diperlakukan dengan tidak baik karena ada sesuatu yang berhubungan dengan kecacatannya (bukan karena kecacatan itu sendiri) tanpa alasan yang logis.

4. Pelecehan, yang mencakup perilaku yang dapat dianggap memiliki efek melanggar hak orang cacat atau menciptakan lingkungan yang ber musuhan, merendahkan, memalukan atau menyinggung.

5. Diskriminasi dengan mengorbankan orang cacat. ( Lockwood, et al., 2014 hlm 169-170) ${ }^{12}$

Keadaan ini mencerminkan kondisi kehidupan pada umumnya dan kebijaksanaan sosial ekonomi dari masa ke masa, akan tetapi dalam bidang kecacatan terdapat pula keadaan-keadaan khusus yang telah mempengaruhi kondisi kehidupan para penyandang cacat. Kurangnya perhatian, takhayul serta rasa

12 Lockwood, G., Claire, H., G. Thornicroft. 2014. Mental health disability discrimination: Law, policy and practice. International Journal of Discrimination and the Law, 14(3) hlm. 169-170 takut merupakan faktor-faktor sosial yang dalam sepanjang sejarah kecacatan telah mengucilkan para penyandang cacat dan menghambat perkembangannya.

Implikasi teoritis untuk menambah kan kecacatan pada hak asasi manusia yang ada, baik untuk individu penyandang cacat maupun bagi orang-orang terlindungi lainnya. Ini mengembangkan paradigma hak asasi manusia penyandang cacat yang menyediakan kerangka kerja komprehensif untuk memastikan pengembangan bakat dan intelektual. hak-hak disabilitas seperi hak-hak sipil dan politik serta hak-hak ekonomi, sosial, dan budaya, kerangka hak penyandang cacat menghadirkan penegas an kembali yang kuat bahwa perlindungan hak asasi manusia yang mapan juga tidak dapat dibagi. Kedua jenis hak sangat penting jika undang-undang yang keras harus efektif. Oleh karena itu, kelompok yang hak-haknya terbagi secara historis antara hak generasi seperti perempuan dapat diperkuat oleh paradigma hak penyandang cacat. (Stein, $2007 \mathrm{hlm} \mathrm{75).}{ }^{13}$

Berbagai Undang-Undang yang telah memperkuat pemerataan kesempatan kerja bagi penyandang disabiitas adalah Undang-Undang Nomor 8 Tahun 2016 tentang Penyandang Disabilitas, UndangUndang Nomor 39 Tahun 1999 tentang Hak Asasi Manusia pada Pasal 38 dan Undang-Undang Nomor 13 Tahun 2003 Ketenagakerjaan pada Pasal 5. Di dalam Undang-Undang yang terkait dengan hak dan kewajiban Penyandang Disabilitas, Pemerintah dan Pemerintah Daerah serta Pemberi Kerja (Perusahaan) sudah diatur secara jelas.Aturan-aturan tersebut adalah sebagai berikut:

1) Undang-Undang Dasar Republik Indonesia Tahun 1945 Pasal $28 \mathrm{D}$ ayat

2) Undang-Undang Nomor 8 Tahun 2016 tentang Penyandang Disabilitas khususnya Pasal 45-49, 51-54, 57, 60 dan 145

13 Stein, M. A. (2007). Disability Human Rights. California Law Review, 95 (1) hlm. 75 
3) Undang-Undang Nomor 13 Tahun 2003 tentang Ketenagakerjaan khususnya Pasal 67

4) Undang-Undang Nomor 40 Tahun 2004 tentang Sistem Jaminan Sosial Nasional khususnya Pasal 13

5) Peraturan Pemerintah Nomor 43 Tahun 1998 tentang Upaya Peningkatan Kesejahteraan Sosial Penyandang Cacat khusunya Pasal 26 dan 28.

Kulkarni (2016 hlm.15) ${ }^{14}$ menyata kan bahwa dalam dunia kerja kecacatan dikaitkan dengan rata-rata gaji, keamanan kerja, pelatihan dan partisipasi yang rendah dalam keputusan, dan sikap negatif terhadap pekerjaan dan organisasi, namun beberapa pengusaha memastikan bahwa semua karyawan diperlakukan dengan adil dan sensitif sehingga semuanya produktif dan dihargai sebagai anggota angkatan kerja di perusahaan mereka. Keputusan seorang pekerja disabilitas di tempat kerja bergantung pada berbagai faktor yang berfungsi pada tingkat intrasituasi, interpersonal, organisasional, dan masyarakat. Pekerja disabilitas seharusnya tetap mendapatkan kesempatan yang sama mengenai pengungkapan dan permintaan akomodasi, keselamatan dan kesejahteraan pekerja (santuzzi \& waltz, 2016 hlm.13).

\section{KESIMPULAN}

Berbagai undang-undang dan peraturan pemerintah di beberapa negara termasuk indonesia, telah ditetapkan guna melarang diskriminasi atas dasar disabilitas terhadap segala bentuk pekerjaan, mencakup kondisi perekrutan, keterampil an, pelayanan penempatan dan keahlian serta pelatihan keterampilan dan ber kelanjutan. Namun tidak tersedianya layanan informasi yang lengkap mengenai potensi dan kemampuan tenaga kerja

14 Kulkarni, M. 2016. Organizational career development initiatives for employees with a disability. The International Journal of Human Resource Management. Hlm. 15 penyandang disabilitas yang dapat diakses oleh pelaku usaha masih menjadi hambatan. Disamping itu berdasarkan analisis Undang-Undang maka UndangUndang tersebut sudah memberikan perlindungan terhadap kaum penyandang disabilitas dengan baik, sehingga dalam mewujudkan hak penyandang disabilitas untuk memperoleh pekerjaan sudah terjamin dan dilindungi namun tetap dalam aplikasinya masih belum terlihat.

\section{SARAN}

Untukpemenuhan kesejahteraan bagi penyandang disabilitas dalam mendapatkan pekerjaan, upah dan perlindungan, maka pemerintah harus mengupayakan perlindungan tersebut agar tidak adanya diskrimanasi terhadap penyandang disabilitas dengan orang normal dan pemerintah juga harus memberikan hak-hak yang sama bagi penyandang disabilitas untuk mendapatkan pekerjaan seperti halnya orang normal.

Pemerintah harus memantau setiap perusahaan untuk memperkerjakan penyandang disabilitas sesuai dengan undang-undang dan memberkan fasilitas yang baik khususnya bagi penyandang disabilitas. Untuk perusahaan di harapkan memberikan aksibilitas dan memberikan hak kesetaraan bagi pekerja penyandang disabilitas dan orang normal. Untuk masyarakat agar stop berpandangan negatif terhadap pekerja disabilitas.

\section{DAFTAR PUSTAKA}

Arikunto, Suharsimi, 2006,Prosedur Penelitian, Suatu Pendekatan Praktik. Rineka Cipta, Jakarta.

Deddy, Mulyana, 2006,Metode Penelitian Kualitatif, Remaja Rosdakarya, Bandung.

Hardjanti, D. K., 2016, Kajian Yuridis tentang Penyandang Disabilitas. Perspektif Hukum, 16 (1), hlm. 117. 
Hardy, I., Woodcock, S., 2015, Inclusive Education Policies: Discourses Of Difference, Diversity And Deficit. International Journal of Inclusive Education. 19(2), hlm. 141-164,

Hemmingsson, H., \& Jonsson, H., 2005, The issue is-An occupational perspective on the concept of participation in the international classification of functioning, disability and health-Some critical remarks. American Journal of Occupational Therapy, 59, hlm. 569-576.

Krieger, N. 2014. Discrimination And Its Consequences For Health : Discrimination And Health Inequities. International Journal of Health Services, 44 (4), hlm. 643-710.

Kulkarni, M. 2016. Organizational career development initiatives for employees with a disability. The International Journal of Human Resource Management, hlm. 1-18.

Kusumastuti, M. N. S. A, 2016, Perlindungan Hukum Dari Diskriminasi Bagi Penyandang Disabilitas Dalam Dunia Kerja. Jurnal Universitas Atma Jaya Yogyakarta.

Lockwood, G., Claire, H., G. Thornicroft, 2014, Mental health disability discrimination: Law, policy and practice. International Journal of Discrimination and the Law, 14(3), hlm. 168-182.
Rosenthal, E. \& Leonard S. R., 1993, International Human Rights under the Advocacy Protection of Persons with Mental Illness. Intenational Journal of Law end Psychiatry, 16, hlm. 257-300.

Santuzzi, A. M., P. R. Waltz, 2016, Disability in the Workplace: A Unique and Variable Identity. Journal of Management, 20 (10), hlm. $1-25$

Stein, M. A., 2007, Disability Human Rights. California Law Review, 95 (1), hlm. 75-121

Szmukler, G, Rowena, D., Felicity, C., 2014, Health Law And The UN Convention On The Rights Of Persons With Disabilities. International Journal of Law and Psychiatry 37, hlm. 245-252

Undang-Undang Dasar Republik Indonesia 1945

Undang-Undang Nomor 13 Tahun 2003 tentang Ketenagakerjaan.

Undang-Undang Nomor 43 Tahun 1998 tentang Upaya Peningkatan Kesejahteraan Sosial Penyandang Cacat.

Undang-Undang Nomor 8 Tahun 2016 tentang Penyandang Disabilitas. 